\title{
The Challenges of Small Industry of Woven Bamboo Craftsmen to Meet Industrial 4.0 in District of Majalengka, West Java, Indonesia
}

\author{
Juliati Prihatini ${ }^{1}$ \\ \{julie_pri@yahoo.com ${ }^{1}$ \} \\ ${ }^{1}$ Institut Pemerintahan Dalam negeri (IPDN), Jl. Raya Bandung Sumedang Km. 20 \\ Jatinangor, Sumedang 45363 West Java, Indonesia
}

\begin{abstract}
The Small and Medium of Industry in Indonesia become of the backbone for the society economicals system, because can penetrate workers without especially skills, so the small industry of woven bamboo craftsmen in Village of Karayunan. This research fulfilled in Village of Karayunan, Subdistrict of Cigasong, District of Majalengka, West Java. In Village of Karayunan there are 10 units of a small industry of woven bamboo craftsmen (Department of Small and Medium Enterprises Group of Industry and Trade of District of Majalengka, 2014) with average account labour 5 persons, but that potential has not been explored maximally. So that is a need to be facilitated from Centre of Government although Region of Government about organize of management and ease to can capital for managers of a small industry of woven bamboo craftsmen so the income for him and workers can increase. The purpose of this study was to know and analyze income from managers and workers of a small industry of woven bamboo craftsmen. The method in this research is qualitative, the technique of collect field data with observation, interview of semi-structure and interview of a structure. The informant in this research account 17 persons. The result of this research show that the product of small industry of woven bamboo craftsmen in Village of Karayunan are "bilik batik", "bilik polos", "bilik kodi" and "kurung". Along time which allocation work not the same about four products. The managers of a small industry of woven bamboo craftsmen could profit from "bilik batik" amount Rp 3.597.500/month; "bilik polos" amount Rp 1.190.000/month; "bilik kodi" amount 2.100.000/month and "kurung" amount Rp 1.353.000/month. Income from the workers of a small industry of woven bamboo craftsmen as a"buruh tani" amount Rp 300.000 - Rp 360.000/month. After became as a worker of a small industry of woven bamboo craftsmen from "bilik batik" amount Rp 1.755.000/month; "bilik polos" amount Rp 1.500.000/month; "bilik kodi" amount 1.050.000/month and "kurung" amount Rp 735.000/month. The conclusion of this research is the small industry of woven bamboo craftsmen can penetrate workers and increase income.
\end{abstract}

Keywords : the government's facilities, small industry, incom 


\section{Introduction}

Now, in this situation about globalization is influential to economics national especially economic of peoples so poverty and sunk happened. Unemployment, limit of a sphere of activity, the fluctuating of rupiah value and so on need to thought of solution so Indonesia no crisis.

Society has an opportunity to active, roll in economic development with the purpose of productivity increasing in livelihood including small industry. It can penetrate workers because management of it didn't difficult, but needed about skill and work hard, besides the need to no much capital relativity.

The village of Karayunan is one of a village in Subdistrict of Cigasong, District of Majalengka has 10 small industries of woven bamboo craftsmen than another village in Subdistrict of Cigasong (Department of Small and Medium Entreprises Group of Industry and Trade of District of Majalengka, 2014)[6]. This small industry of woven bamboo craftsmen as a society profession, so interlocked with society's income.

The small industry of woven bamboo craftsmen in Village of Karayunan not potentially yet. Limited for capital who manager's of a small industry of woven bamboo craftsmen, tighten to the procedure which give credit to manager's of a small industry of woven bamboo craftsmen and so on are problems which give a solution, exactly about raw materials that is bamboo in stock enough in this village. Because of that to meet the challenges about industry 4.0 of revolution so the Centre of Government and Region of Government that is District of Majalengka need to attitude by organizing building and facilitation.

\section{Study of Literature}

\subsection{Empowerment}

Perkins \& Zimmermen (1995) [1] said that the empowerment to show two tendencies are: First: the empowerment sign to give or remove for the greater part of power, strength or capacity to society, organization, individual so become more to do best. Second: a tendency of seconder sign to the process of stimulation, to push and to motivate so that have to power or to exert for secure what do choose in his/her life.

\subsection{Small Industry}

The characteristic for small industry base on quality and type are [2]:

1) Base for local of resources so that useful about maximal for potency and strengthen to itself;

2) Occupied and carried out by local society so that able to development for human resources;

3) Useful indigenous technology so that carried out and had development by power of local;

4) Scattered in quantity so that is equal for effective development.

The Office of Statistic Centre (BPS Indonsia) (2004) said that the classification of industry base on the quantity of workers in used are [7] :

1) Big industry if the worker as much as 100 peoples or more;

2) Medium industry if the worker as much as $20-99$ peoples;

3) Small industry if the worker as much as $5-19$ peoples;

4) Home industry if the worker as much as $1-4$ peoples. 
Basic of the problem which meet from small of managers based on Caliendo \& Kritikos (2010) are [3]:

1) Powerlessness in receive of market opportunity and enlarge of part of market;

2) Powerlessness in structure of capital and limited to access for sources of capital;

3) Powerlessness in organization a management of human capital;

4) Limited of networking one small manager to another (system of marketing information);

5) Not integrated of erection yet and lack of trust and take notice of society towards small of effort.

\subsection{Income of Society}

Milanovic (2005) said that income means income of aggregate (from various sources) in actual acceptanced by someone or household [4].

\section{Method}

Design of Research in this research is qualitative with analysis descriptive method. The method of qualitative [5] is a method of research which used to research to nature object condition, who researcher as a key instrument, the technique data gathering carried out a mix, characteristic data analysis is inductive and result of qualitative research more to design meaning than generalization [3]. Primary and secondary data in this research as data sources. In this research, informant as a primary data whose author's interview account 17 peoples. The technique of data gathering in this research carried out with observation, interview of semi structure and interview of the structure. This research fulfiled on April - Oktober 2014 in Village of Karayunan, Subdistrict of Cigasong, District of Majalengka, West Java.

\section{Result}

The product of small industry of woven bamboo craftsmen which produce by manager's and workers in Village of Karayunan are "bilik batik, bilik polos, bilik kodi and kurung". Table 1 below to serve an average of income for managers of a small industry of woven bamboo craftsmen in Village of Karayunan.

Table 1. The Average of Income for Manager's of Small Industry of Woven Bamboo

\begin{tabular}{llcrrr}
\multicolumn{7}{c}{ Craftsmen in Village of Karayunan } \\
\hline No & $\begin{array}{l}\text { Various of Small } \\
\text { Industry of Woven }\end{array}$ & $\begin{array}{c}\text { Amount of } \\
\text { Production }\end{array}$ & Capital (Rp) & $\begin{array}{c}\text { The result of } \\
\text { Sold Out (Rp) }\end{array}$ & $\begin{array}{c}\text { Profit/month } \\
\text { (Rp) }\end{array}$ \\
& Bamboo Craftsmen & & & & \\
\hline 1 & Bilik batik & $432 \mathrm{~m}$ & 7.202 .500 & 10.800 .000 & 3.597 .500 \\
2 & Bilik polos & $90 \mathrm{~m}$ & 610.000 & 1.800 .000 & 1.190 .000 \\
3 & Bilik kodi & 60 golong & 3.900 .000 & 6.000 .000 & 2.100 .000 \\
4 & Kurung & 450 seed & 1.352 .500 & 1.575 .000 & 1.353 .000 \\
\hline
\end{tabular}

The income for workers of a small industry of woven bamboo craftsmen as a "buruh tani" amount Rp 300.000 - Rp 360.000/month. After became as workers of a small industry of woven bamboo craftsmen his income served in table 2 below. 
Table 2 . The Average of Income for Workers of Small Industry of Woven Bamboo Craftsmen in Village of Karayunan

\begin{tabular}{llrr}
\hline No & \multicolumn{2}{c}{$\begin{array}{c}\text { Various of Small Industry of Woven } \\
\text { Bamboo Craftsmen }\end{array}$} & 58.500 \\
\cline { 3 - 4 } & \multicolumn{1}{c}{ Income/days (Rp) } & Income/month (Rp) \\
\hline 1 & Bilik batik & 50.000 & 1.755 .000 \\
2 & Bilik polos & 35.000 & 1.500 .000 \\
3 & Bilik kodi & 24.500 & 1.050 .000 \\
4 & Kurung & & 735.000 \\
\hline
\end{tabular}

\section{Discussion}

The exist of a small industry of woven bamboo craftsmen in Village of Karayunan very help to the economic of society, because it has appointed by the local of society as work to fulfil daily life. Because of that The Department of Small and Medium Entreprises Group of Industry and Trade of District of Majalengka is necessary to deceive for manager's, so that income is increasing.

The figure for the fourth of the small industry of woven bamboo craftsmen and income for the manager's served below.

\subsection{Manager's Income for "Bilik Batik"}

One truck of transportation includes 12 bambooes can make 12 slices of "bilik batik" with every size $3 \times 12 \mathrm{~m}$, as long as one month worked. The price for "bilik batik" amount Rp $25.000 / \mathrm{m}$, so can income amount Rp 10.800.000. Cost of one truck of transportation for buy bamboo as a raw material amount Rp 1.937.500 and cost of 3 workers @ Rp 58.000 amount Rp 5.265.000. Total of cost amount Rp 7.202.500. So profit for managers of a small industry of woven bamboo craftsmen of "bilik batik" amount Rp 3.597.500. 


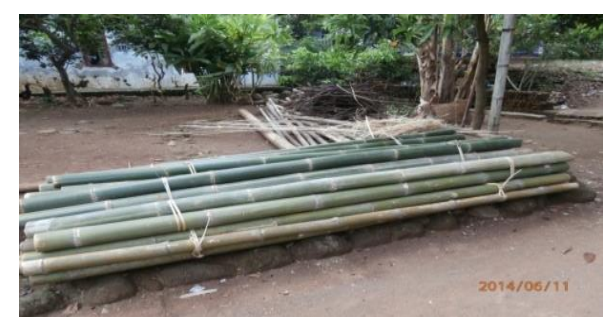

Bamboo has section finished for "bilik batik"

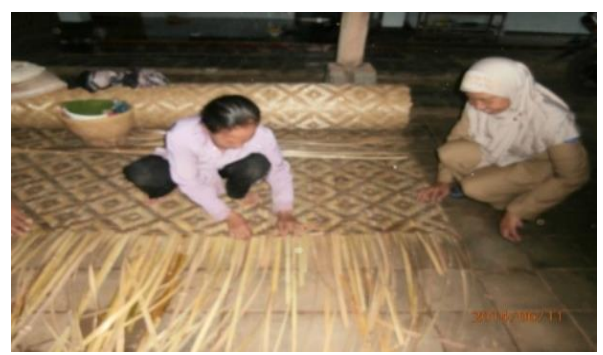

The worker plait for "bilik batik"

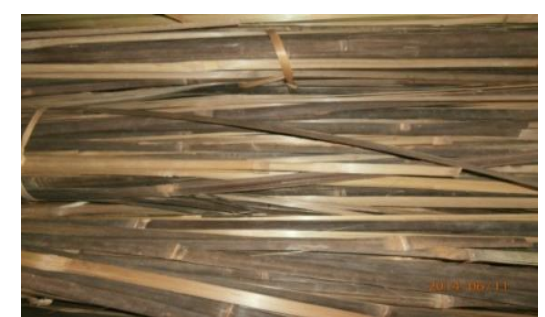

Black and green of bamboo as a raw materials for woven bamboo craftsmen

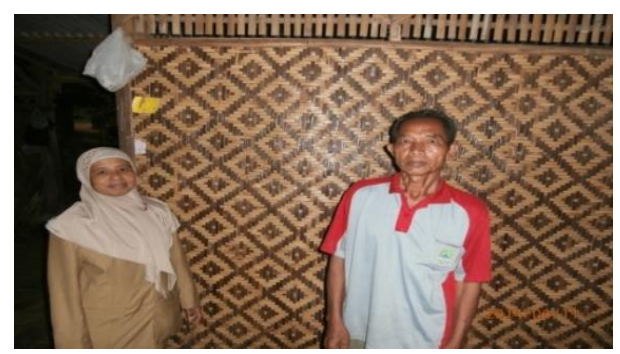

have plait finished

Fig 1. "Bilik Batik"

\subsection{Manager's Income for "Bilik Polos"}

One truck of transportation includes 6 bamboos can make 3 slices of "bilik polos" with every size $3 \times 10 \mathrm{~m}$, as long as 15 days worked. The price for "bilik polos" amount Rp $20.000 / \mathrm{m}$, so can income amount Rp 1.800.000. Cost of one truck of transportation for buy bamboo as a raw material amount Rp 410.000 and cost of 4 workers @ Rp 50.000 amount Rp 200.000. Total of cost amount Rp 610.000. So profit for managers of a small industry of woven bamboo craftsmen of "bilik polos" amount Rp 1.190.000.

\subsection{Manager's Income for "Bilik Kodi"}

Two trucks of transportation include 16 bamboos can made 60 "golong" of "bilik kodi" with every size $2 \times 2 \mathrm{~m}$, as long as one month worked. Black bamboo is raw material for "bilik batik". "Bilik kodi" is part of black bamboo and the deepest. The raw material for "bilik kodi" made by the workers of a small industry of woven bamboo and if work finished sold to managers. The price for "bilik kodi" amount Rp 65.000. So 60 "golong" for "bilik kodi" to sold to manager's is amount Rp 3.900.000. The price of "bilik kodi" if to sold to society amount Rp 100.000/"golong". The income for 60 "golong" amount Rp 6.000.000. So profit for managers of a small industry of woven bamboo craftsmen of "bilik kodi" amount Rp 2.100.000. 


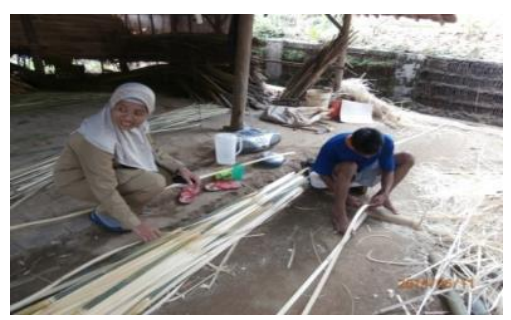

The worker doing section

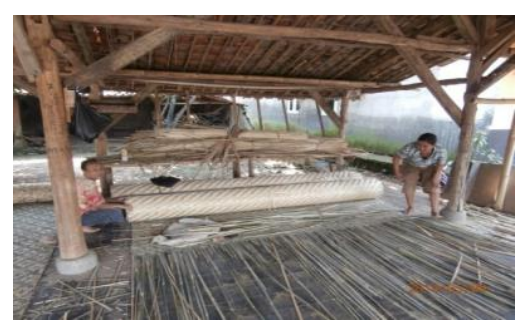

The worker plaint for "bilik polos"

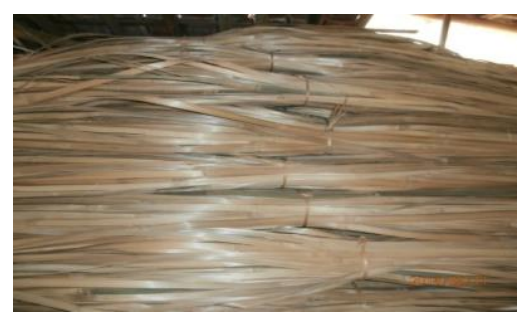

The deepest of green bamboo as a raw materials for "bilik polos"

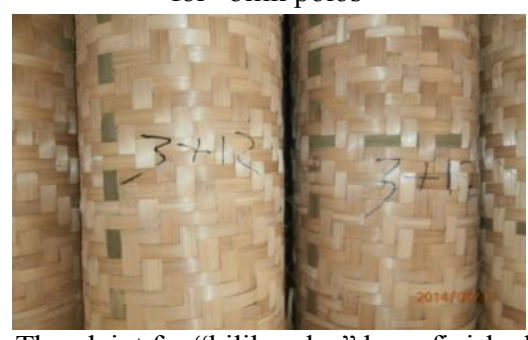

The plaint for "bilik polos" have finished

Fig 2. "Bilik Polos"

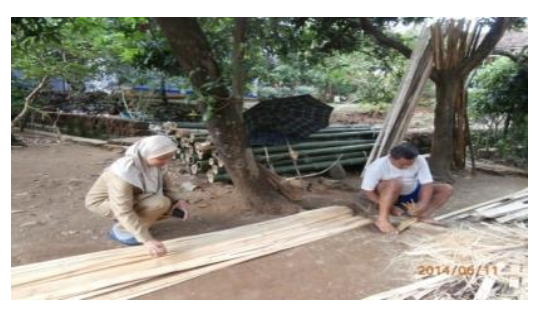

The worker doing section of bamboo for "bilik kodi"

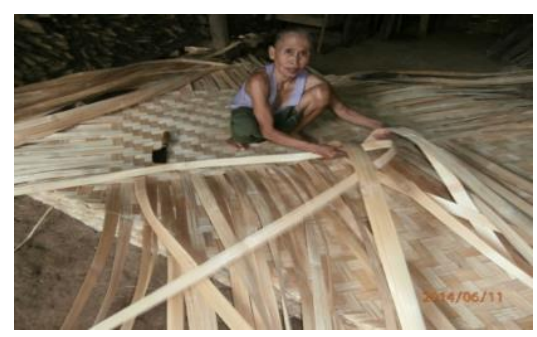

The worker plaint for "bilik kodi"

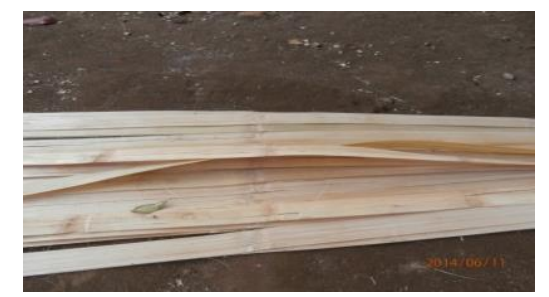

The result of section for the deepest of black bamboo as a raw materials for "bilik kodi"

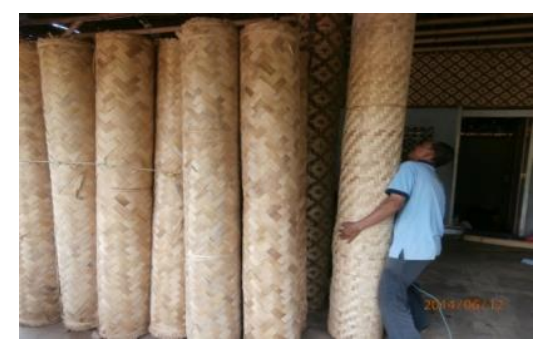

"Bilik Kodi have plaint finished

Fig. 3. "Bilik Kodi" 


\subsection{Manager's Income for "Kurung"}

One truck of transportation of 15 bamboos can make 450 seeds of "kurung" as long as 5 days working .The price for "kurung" amount Rp 3.500/seed, so can income amount Rp 1.575.000. Cost of one truck of transportation for buy bamboo as a raw material amount $\mathrm{Rp}$ 1.254.500 and cost of 4 workers @ Rp 24.500 amount Rp 98.000. Total of cost amount Rp 1.352.500. So profit for managers of a small industry of woven bamboo craftsmen of "kurung" amount Rp 225.500 as long as five days. In one month, the profit amount 30/5 x Rp 225.500= $\operatorname{Rp} 1.353 .000$.

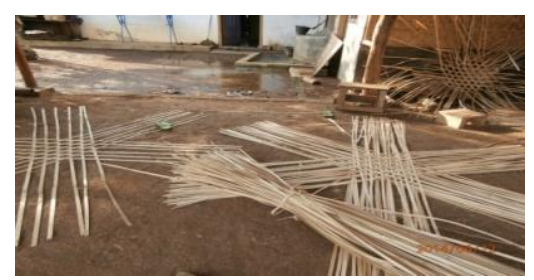

Figure 13. The worker prepare for plaint to "kurung"

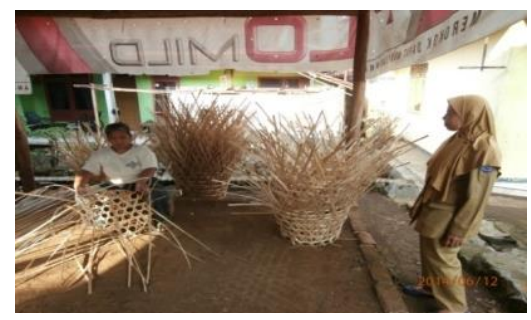

Figure 15. The worker has plait to "kurung"

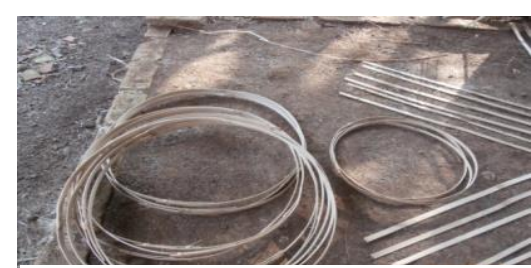

Figure 14. The top and buttom of "bengkel" for "kurung"

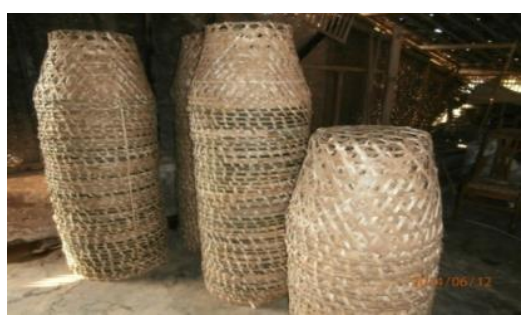

Figure 16. "Kurung" have plait finished

Fig. 4 "Kurung"

The four product of small industry of woven bamboo craftsmen based on capital and more or less of an effort of scale from managers. So managers of small industry of woven bamboo craftsmen in Village of Karayunan in one month average can produce "bilik batik" as much as 12 slices with size $3 \times 12$ m; "bilik polos" as much as 3 slices with size $3 \times 10$ m; "bilik kodi" as much as 60 "golong" with size $2 \times 2$ m and kurung as much as 450 seeds. Base on the above the average income for manager's of a small industry of woven bamboo craftsmen amount Rp 1.353.000 - Rp 3.597.500/month.

In the process of a product that more or less capital effort, amount of commodities which produced and various commodities which produced to the amount of income influential. Base on "Surat Edaran Bupati" Nomor 651/1956/2013 November 26 2013 about Minimum of Fee for Labour that there are two categories in District of Majalengka, for General with Minimum of Fee for Labour amount Rp 1.000.000/month and for Industry with Minimum of Fee for Labour amount Rp 1.130.000/month.

Comparison for income with Minimum of Fee for Labour in District of Majalengka that the income for manager's and workers of a small industry of woven bamboo craftsmen are 
above from Minimum of Fee for Labour in District of Majalengka. It means that income has enough if comparison with before manager's and workers not work in a small industry of woven bamboo craftsmen yet. They are work as a "buruh tani", because didn't have land to farm operations. Only for the smaller part who has agricultural land, because of that the small industry of woven bamboo craftsmen in Village of Karayunan as a work from people.

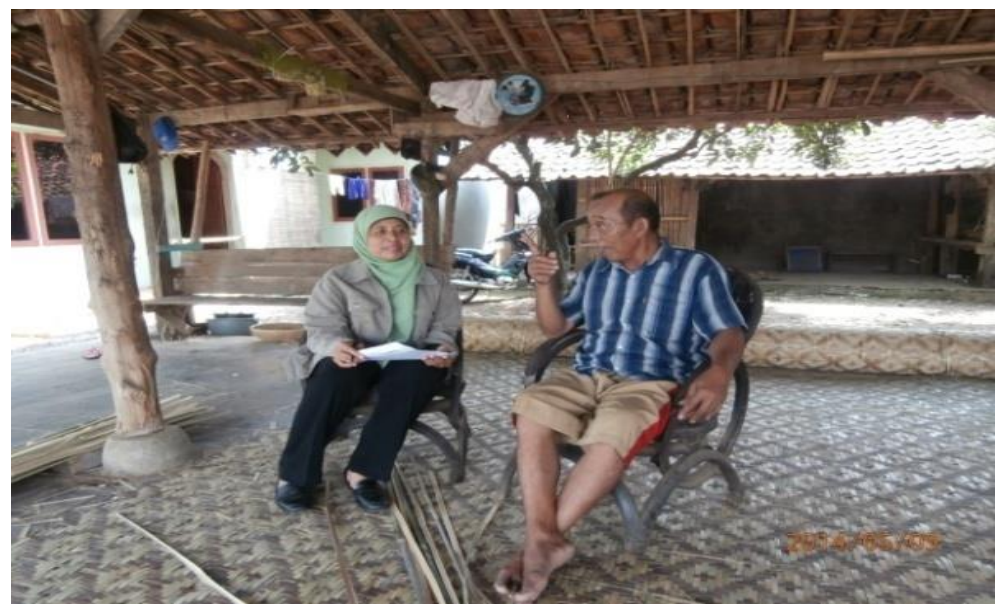

Fig. 5. Interview Author with Mr. Karta one of the managers for the small industry of woven bamboo craftsmen on Mei $12^{\text {th }} 2014$. He said that in one day manager's can produce for "bilik batik" as much as 0,5 slice; with size $3 \times 12 \mathrm{~m}$ as long as 2 days worked. Produce of "bilik kodi" as much as $1-2$ "golong" with size $3 \times 12 \mathrm{~m}$, because 2 trucks of transportation are produced as much as 60 "golong" and as long as one month worked. Produce of "bilik polos" as much as 0,2 slice with size $3 \times 10 \mathrm{~m}$, because one truck of transportation is producing 3 slices as long as 2 weeks worked. Produce for "kurung" as much as 90 seeds, because produce of one truck of transportation is 450 seeds and as long as 5 days worked.

Interview Author with Mr. Ujang as a worker of a small industry of woven bamboo craftsmen on May $11^{\text {th }} 2014$ said that cost of children's education fulfiled from income who acceptance every month as a worker in a small industry of woven bamboo craftsmen. Necessary the motivate to the children is a spirit of learning, remember his/her parents only passed an examination from Elementary School and Secondary School. That factors cause impact to the children to go out of school and they have the assumption that becomes to the worker in a small industry of woven bamboo craftsmen not important high education but skill is very important.

Further, interview Author with Mr. Ahmid as a Head of Village of Karayunan on May $11^{\text {th }} 2014$ said that small industry of woven bamboo craftsmen in Village of Karayunan can increasing income for workers although the income didn't amount of great. Now the workers of a small industry of woven bamboo craftsmen in Village of Karayunan has fixed work, so the amount of unemployment can surpass.

A small industry of woven bamboo craftsmen in Village of Karayunan as a working primary and they hope can penetrate unemployment in Village of Karayunan. Table 3 below serve about data of unemployment in Village of Karayunan. 
Table 3. Data of Unemployment Anxious in Village of Karayunan

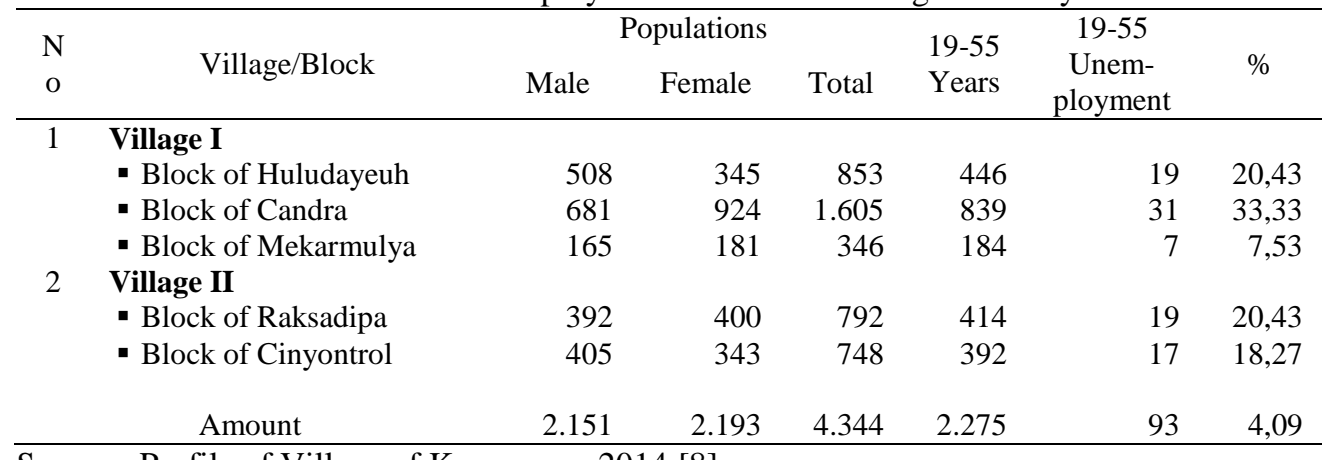

Source : Profile of Village of Karayunan, 2014 [8]

Table 3 shows that the number of peoples in 19 - 55 years are productive age in Village of Karayunan as much as 2.275 peoples, which 93 people unemployment categories. So small industry of woven bamboo craftsmen has the opportunity to penetrate workers which still unemployment to become workers of a small industry of woven bamboo craftsmen. The capacity of managers of a small industry of woven bamboo craftsmen different one manager's to another manager's in penetrating about workers, that is based on various and amount of woven bamboo craftsmen produced.

The small industry of woven bamboo craftsmen in Village of Karayunan can penetrate more workers than another small industry. That is 129 peoples $(79,14 \%)$; shop of car as much as 5 peoples $(3,07 \%)$; shop of weld as much as 1 people $(0,61 \%)$; shop of motor cycle as much as 2 peoples $(1,23 \%)$; shop of car, weld and paint as much as 5 peoples $(3,07 \%)$; eternit as much as 4 peoples $(2,45 \%)$; mebeuler as much as 10 peoples $(6,13 \%)$; paving block as much as 1 people $(0,61 \%)$ and red of tile as much as 6 peoples $(3,68 \%)$ (Source : Profile of Village of Karayunan, 2014) [8].

The interlocked to meet industry 4.0 of revolution, a small industry of woven bamboo craftsmen in Village of Karayunan ever gave the material in 2014 from Department of Small and Medium Enterprises Group of Industry and Trade of District of Majalengka and served in table 4 below.

Table 4. Contribution of Material for Small Industry of Woven Bamboo Craftsmen in Village of Karayunan from Department of Small and Medium Enterprises Group of Industry and Trade of District of Majalengka

\begin{tabular}{clc}
\hline No & \multicolumn{1}{c}{ Various of Material } & Amount \\
\hline 1 & The machine of Bamboo Splited & 1 unit \\
2 & Knife & 20 seeds \\
3 & Saw & 20 seeds \\
4 & A pair of Scissors & 20 seeds \\
5 & Metre & 20 seeds \\
\hline
\end{tabular}

Source : Department of Small and Medium Enterprises Group of Industry Trade of District of Majalengka, 2014 [6]

Interview Author with Mr. Asep Iwan as a Head of Industrial Department on Department of Small and Medium Enterprises Group of Industry and Trade of District of Majalengka on May $12^{\text {th }} 2014$ said that the institution had to do the effort, so that small industry of woven 
bamboo craftsmen for increasing the product than before giving materials. But in reality, the machine of bamboo splited didn't use, because in operational necessary 1300 watt, manager's has 450 watts only in his house. Nevertheles to put on traditional materials but the product of small industry of woven bamboo craftsmen in Village of Karayunan is producing of soft and proper. That product can be more soft and proper if the machine of bamboo spliten used by managers and workers of a small industry of woven bamboo craftsmen. Because of that managers and workers hope to material contribute from the Region of Government in used.

\section{Conclusion}

The production of "bilik batik" as much as $432 \mathrm{~m}$ with size $3 \times 12 \mathrm{~m}$ and income for manager's amount Rp 3.597.500/month; "bilik polos" as much as $90 \mathrm{~m}$ with size $3 \times 10 \mathrm{~m}$ and income amount Rp 1.190.000/month; "bilik kodi" as much as 60 "golong” with size 2 x 2 m and income amount Rp 2.100.000/month and "kurung" as much as 450 seeds and income amount Rp 1.353.000/month.

Income for the workers from "bilik batik" amount Rp 1.755.000/month; "bilik polos" amount Rp 1.500.000/month; "bilik kodi" amount Rp 1.050.000/month and "kurung" amount Rp 735.000/month. For meet industry 4.0 of revolution, managers of a small industry of woven bamboo craftsmen in Village of Karayunan hope to facilitation from Centre of Government and Region of Government especially Department of Small and Medium Enterprises Group of Industry and Trade of District of Majalengka, that is materials in used for manager's and the workers. Beside that necessary about errection of organization management.

Necessary to give skill are AMT (Achievement Motivation Training) and GMP (Good Manufacturing Practice), because the two skills in District of Majalengka just gave to managers of IKM Food in 2013. Necessary to give ease in permission of effort, so if the capital from managers of limited can borrow to economics institution. Support to increase for access and part of the market

\section{References}

[1] D. D. Perkins and M. A. Zimmerman, "Empowerment theory, research, and application," Am. J. Community Psychol., 1995.

[2] U. Aswathanarayana, "Industry," in Green Energy: Technology, Economics and Policy, 2010.

[3] M. Caliendo and A. S. Kritikos, "Start-ups by the unemployed: Characteristics, survival and direct employment effects," Small Bus. Econ., 2010.

[4] B. Milanovic, "Global Income Inequality: What it is and Why it Matters?," 2005.

[5] Sugiyono, "Memahami Penelitian Kualitatif," Bandung Alf., 2016. 